\title{
GÜNCEL FİSSÜR ÖRTÜCÜLER - LİTERATÜR DERLEMESİ
}

\section{CURRENT FISSURE SEALANTS - LITERATURE REVIEW}

Uzm.Dt. Ece ÜNLÜGENÇ*
Prof.Dr. Behiye BOLGÜL*

\author{
Makale Kodu/Article code: 4065 \\ Makale Gönderilme tarihi: 07.05.2019 \\ Kabul Tarihi: 20.09.2019
}

DOI : $10.17567 /$ ataunidfd.622677
Ece Ünlügenç: $O R C I D I D: \quad 0000-0003-3833-3444$

Behiye Bolgül: ORCID ID: 0000-0003-4425-1875

\section{öz}

Günümüzde, diş çürüğü, oral sağlığı etkileyen önemli bir problem olma durumunu hala korumaktadır. Pit ve fissür çürükleri oldukça erken yaşlarda görülen bir hastalıktır ve bukkal ve lingual yüzeylerdeki çürükler dikkate alındığında pit ve fissürlerde oluşan çürükler, çocuk ve ergenlerdeki tüm çürük deneyiminin \%80'inden fazlasını oluşturmaktadır. Pit ve fissürleri korumak için daha etkili önlemler alınması gerekir; bunlar arasında pit ve fissür örtücü maddesi kullanımı bulunur. Fissür örtücüler, diş çürüklerini önlemek amacıyla dişlerdeki pit ve fissürlere uygulanan materyallerdir. Örtücü uygulaması, örtücü maddelerinin çürüklere yatkın dişlerin pit ve fissürleri içerisine girmesini sağlayan koruyucu bir yaklaşımdır; bu örtücü maddesi daha sonra dişe mikromekanik olarak yapışarak bakterileri besin kaynaklarından uzak tutan fiziksel bir bariyer görevi görür Farklı örtücü malzemelerin arasında en iyi sseçimin belirlenmesi karmaşık olabilir. Diş hekimleri seçebileceği ürünleri, çürük önleyici etki, florür salınımı ve retansiyon oranı gibi farklı özelliklere bakarak karar vermektedir. Bu derlemede, literatür gözden geçirilerek, pit ve fissür örtücülere genel bir bakış, örtücü olarak kullanılan materyallerdeki gelişmeler, ayrıca endikasyonlar, uygulama yöntemleri ve olası yan etkileri hakkında bilgi vermek amaçlanmışır.

Anahtar Kelimeler: pit ve fissür örtücü, çürükten korunma, daimi ve süt dişi

\section{ABSTRACT}

Today, tooth decay remains a major problem affecting oral health. Pit and fissure caries is a disease that occurs at a very early age, and when the caries on the buccal and lingual surfaces are taken into account, caries formed in pits and fissures constitute more than $80 \%$ of all caries experience in children and adolescents. More effective measures must be taken to protect the pit and fissures; these include the use of pit and fissure sealant. Fissure sealants are materials that are applied to pit and fissures in the teeth to prevent tooth decay. The application of the sealant is a protective approach that allows the sealants to penetrate into the pits and fissures of the teeth prone to decay; this sealant agent then adheres to the tooth micromechanically and acts as a physical barrier that keeps bacteria away from food sources. Determining the best choice among different sealant materials can be complex. Dentists decide the products they can choose by looking at different characteristics such as caries preventive effect, fluoride release and retantion rate. In this review, it is aimed to give a general overview of pit and fissure sealants, developments in materials used as coverings, indications, application methods and possible side effects.

Keywords: pit and fissure sealant, caries prevention, permantent and deciduous teeth

\footnotetext{
*Hatay Mustafa Kemal Üniversitesi Diş Hekimliği Fakültesi, Pedodonti Anabilim Dalı, Hatay.
}

Kaynakça Bilgisi: Ünlügenç E, Bolgül B. Güncel Fissür Örtücüler - Literatür Derlemesi. Atatürk Üniv Diş Hek Fak Derg 2020; 30 : 507-18. Citation Information: Unlugenc E, Bolgul B. Current Fissure Sealants - Literature Review. J Dent Fac Atatürk Uni 2020; 30: 507-18.

\section{GİRİş}

Diş çürüğü, bakteri biyofilminin bileşimindeki değişimin neden olduğu, demineralizasyon ve remineralizasyon süreçleri arasında bir dengesizliğe yol açan ve süt ve kalıcı dişlerde çürük lezyonlarının oluşumu ile ortaya çıkan çok faktörlü bir hastalıktır. ${ }^{1} \mathrm{Bu}$ nunla birlikte, diş çürüğü en yaygın intraoral hastalıklardan biridir ve hem bireysel hem de halk için tıbbi, sosyal ve ekonomik kaygılar açısından ciddi sonuçları vardır. ${ }^{2}$ Son yıllarda diş hekimliği, çürük riskini azaltma, koruyucu önlemlerin alınması ve dental yapıların korunmasına yönelik non-invaziv konservatif teknikler üzerine odaklanmaktadır.Bu amaçla beslenme düzenlenmesi, ağız hijyen eğitiminin verilmesi, flor uygulamaları, flor içeren dental materyallerin kullanılması ve fissür örtücü uygulamaları gibi çok çeşitli yaklaşımlar tercih edilmektedir. ${ }^{3}$ 
Pit ve fissür çürükleri oldukça erken yaşlarda görülen bir hastalık sürecidir. Bukkal ve lingual yüzeylerdeki çürükler dikkate alındığında pit ve fissürlerde oluşan çürüklerin, çocuk ve ergenlerdeki tüm çürük deneyiminin \%80'inden fazlasını oluşturduğu gözlemlenmiştir. Oklüzal yüzeylerde çürük insidansının yüksekliği derin pit ve fissürlerin varlığı ile ilişkilidir ve bu çürükler aynı zamanda pit ve fissür çürüğü olarak da isimlendirilirler. ${ }^{4}$ Toplum sularını florlama, topikal flor tedavisi, plak kontrolü ve diyette şeker kontrolü gibi çürük önleyici yaklaşımların kullanımının, genel olarak çürük prevalansının özellikle de düz yüzey çürük lezyonlarının azalması üzerine daha büyük etkiye sahip olduğu görülmüştür. Pit ve fissürlerin plak tutma özelliği, temizlenmelerini zorlaştırarak, çürüklere düz yüzeylerden daha duyarlı hale gelmelerine ve muhtemelen flor uygulaması ile korunmamasına neden olmaktadır. $^{5}$

Pit ve fissürleri korumak için daha etkili önlemler alınması gerekir; bunlar arasında pit ve fissür örtücü maddesi kullanımı bulunur. Örtücü uygulaması, örtücü maddelerinin çürüklere yatkın dişlerin pit ve fissürleri içerisine girmesini sağlayan koruyucu bir yaklaşımdır; bu örtücü maddesi daha sonra dişe mikromekanik olarak yapışarak bakterileri besin kaynaklarından uzak tutan fiziksel bir bariyer görevi görür. ${ }^{6}$

\section{GELİ̧̧ìi \\ 2. FİSSÜR ÖRTÜCÜLERİN TARİHSEL}

İlk olarak 18. yüzyılın başlarında azı dişlerinin oklüzal yüzeylerinin uygun bir materyel ile örtülmesinin olası çürük lezyonlarının önüne geçilebileceği düşünülmüştür. ${ }^{7}$ İlk tedavi yaklaşımı Wilson tarafından fissürlerin çinko fosfat siman ile örtülmesiyle başlamıştır. ${ }^{8}$ İlerleyen dönemde Hyatt çürük şüphesi olan derin pit ve fissürlerin mekanik olarak aşındırılmasını ve açılan sını 1 kavitelerin amalgam ile doldurulduğu 'profilaktik odontomi' tekniğini gündeme taşımıştır. 1929 yılında Bodecker fissürleri sond ile temizleyip içerisine oksifosfat siman damlatılmasını savunmuştur. Daha sonra fissürlerde kendi kendine temizlenebilen alanlar yaratmak için oklüzal fissürlerin frez ile aşındırarak düzleştirildiği 'fissür eradikasyon tekniğini' önermiştir. ${ }^{10}$

Pit ve fissür örtücülerin ortaya çıkışı, Buonocore tarafından yapılan minenin asitlenmesi ile oluşturulan mikroboşluklara, rezin materyalin sızarak materyalin tutuculuğunun arttırılmasını sağlayan bir çalışmaya dayanmaktadır. ${ }^{11}$ Cueto ve Buonocure tarafından 1967 yılında, asitlenen oklüzal yüzeylerin siyonoakrilat kullanılarak örtülmesi ile fissür örtücülerin ilk klinik uygulamaları başlamış olmuştur. ${ }^{12}$ Ancak siyonoakrilatların deri ve ağız mukozasında oluşturdukları toksik etkiler, uygulamanın zor olması, nemli ortamda zamanla bakteriyel bozulmaya uğramaları, ağız sıvılarında çözünmeleri ve bağlanma kuvvetlerinin düşük olması gibi sebeplerle kullanımlarından vazgeçilmiştir. ${ }^{13}$

Flor içeren ve dişlere fizikokimyasal olarak bağlanabilen cam iyonomer simanlar, Wilson ve Kent tarafından formüle edilerek diş hekimliğinde kullanılabilecek yeni bir materyal olarak piyasaya sunulmuştur. ${ }^{14}$ Cam iyonomer simanları fissür örtücü materyali olarak ilk kullanan ise Mc Lean ve Wilson olmuştur. ${ }^{15}$ Cam iyonomer simanlar uzun süre kullanılmış olsalar da neme karşı duyarlı olmaları, kırılma ve aşınma dirençlerinin düşük olması gibi olumsuz özelliklerini ortadan kaldırmak için içerisine rezin ilave edilerek, rezin modifiye cam iyonomer siman (RMCIS) ve poliasit modifiye kompozit rezin (PMKR) materyalleri geliştirilmiştir. Bu iki materyalin fissür örtücü tipleride üretilmiş ve günümüzde halen klinik uygulamalarda kullanılmaktadır. 16 İlerleyen dönemde Bowen, bisfenol-a-glisidil dimetakrilat adı verilen yapışkan bir rezin icat etmiştir ve bu, BIS-GMA olarak tanındı. 1960'ı yılların sonlarında geliştirilen bis-fenol A glisidil metakrilat (Bis-GMA) rezinler birçok restoratif işlemde başarı ile kullanılmaya başlanmıştır. Bu materyalin bozulmaya karşı dayanıklı olduğu ve asitlenmiş mineye bonding ajan ile başarıyla yapıştığı tespit edilmiştir. ${ }^{17}$ Buonocore, 1970 yılında ultraviyole ışık kullanımıyla BIS-GMA rezinin başarılı bir şekilde kullanılmasını açıklayan pit ve fissür örtücü maddesi hakkında ilk makalesini yayınlamıştır. Amerikan Diş Hekimliği Birliği (American Dental Association-ADA) tarafından 1980'li yıllarda bis-fenol A metakrilat (BisGMA) rezin monomer içerikli fissür örtücü materyallerinin kullanımına izin verilmiştir. ${ }^{18}$

\section{GÜNCEL FİSSÜR ÖRTÜCÜ MATERYALLERİ}

Pit ve fissür örtücü olarak kullanılacak en uygun malzeme hala sorgulanmaktadır. En sık kullanılan örtücü malzemeleri rezin esaslı örtücüler ve cam iyonomer esaslı örtücülerdir. ${ }^{10}$ Rezin esaslı örtücü maddeleri, üretan dimetakrilat (UDMA) veya bisfenol A-glisidil metaakrilat (bis-GMA) monomerlerinden oluşmakla birlikte, cam iyonomer örtücü maddeleri, floroalüminosilikat cam tozu ve sulu bazlı bir poliakrilik asit çözeltisinden oluşur. Rezin esaslı örtücü malzemelerinin en belirgin avantajı dayanıklılıklarıdır, cam iyonomer örtücü maddelerinin ise florür salma özelliği göstermesidir. ${ }^{19}$ Geleneksel cam iyonomer simanların ve rezinlerin avantajlarından yararlanabilmek için, bu iki materyalin farklı oranlarda birleştirilmesiyle, rezin 
modifiye cam iyonomer simanlar ve poliasit modifiye kompozit rezinler (kompomer) materyalleri geliştirilmiştir. Ayrıca materyalin klinik başarısını arttırmak için materyal içerisinde modifikasyonlar yaparak giomer ve cam karbomer esaslı materyaller geliştirilmiştir. ${ }^{20}$ Tablo1'de örtücü materyallerinin sınıflandırılması yapılmıştır.

Tablo 1. Örtücü materyallerinin sınıflandırılması.

\begin{tabular}{|c|c|c|}
\hline Örtücü materyalleri & Alt grupları & $\begin{array}{c}\text { Ticari ürün } \\
\text { örnekleri }\end{array}$ \\
\hline $\begin{array}{l}\text { Rezin esaslı } \\
\text { örtücüler }\end{array}$ & $\begin{array}{c}\text { Opak, } \\
\text { transparan, } \\
\text { dolduruculu, } \\
\text { doldurucusuz, } \\
\text { dltraviyole Işıkla polimeriz }\end{array}$ & $\begin{array}{l}\text { telioseal (Ivoclar Vivadent, } \\
\text { Schaan, Liechtenstein), } \\
\text { Clinpro (3M ESPE, Saint } \\
\text { Paul, MN, ABD), Nuva- } \\
\text { eieal } § \text { (LD. Caulk Co., ABD) }\end{array}$ \\
\hline & $\begin{array}{c}\text { olan, } \\
\text { autopolimerize olan, } \\
\text { Işıkla polimerize olan, } \\
\text { florid içeren }\end{array}$ & $\begin{array}{c}\text { Grandioseal (VOCO, } \\
\text { Almanya), Fissurit FX } \\
\text { vOCO, Almanya), Ultrasea } \\
\text { XT Hydro (Ultradent, USA) }\end{array}$ \\
\hline \multirow{4}{*}{$\begin{array}{l}\text { Cam iyonomer } \\
\text { siman esaslı } \\
\text { örtücüler }\end{array}$} & $\begin{array}{l}\text { Konvansiyonel cam } \\
\text { iyonomer esaslı örtücüler }\end{array}$ & $\begin{array}{l}\text { GC fuji triage (GC Dental, } \\
\text { ABD), Riva Protect (SDI, ) }\end{array}$ \\
\hline & $\begin{array}{l}\text { Rezin modifiye cam } \\
\text { iyonomer esaslı örtücüler }\end{array}$ & $\begin{array}{l}\text { GC fuji II LC (GC Dental, } \\
\text { ABD), Meron plus (VOCO, } \\
\text { Almanya) }\end{array}$ \\
\hline & Giomer esaslı örtücüler & $\begin{array}{c}\text { BeautiSealant (Shofu } \\
\text { Dental, Tokyo) }\end{array}$ \\
\hline & $\begin{array}{c}\text { Cam karbomer esaslı } \\
\text { örtücüler }\end{array}$ & $\begin{array}{l}\text { GCP Glass Seal (GCP } \\
\text { Dental, Hollanda) }\end{array}$ \\
\hline $\begin{array}{l}\text { Poliasid modifiye } \\
\text { rezin esaslı } \\
\text { örtücüler }\end{array}$ & & $\begin{array}{c}\text { Dyract Seal (Dentsply, } \\
\text { Almanya) }\end{array}$ \\
\hline $\begin{array}{l}\text { Ormoser esaslı } \\
\text { örtücüler }\end{array}$ & & $\begin{array}{c}\text { Admira Seal (VOCO, } \\
\text { Almanya) }\end{array}$ \\
\hline
\end{tabular}

\subsection{REZİN ESASLI FİSSÜR ÖRTÜCÜLER}

Günümüzde rezin esaslı fissür örtücüler yapısal özellikleri göz önünde bulundurulduğunda; renklerine, polimerizasyon şekillerine ve doldurucu içeriklerine göre sınıflandırılmaktadır. ${ }^{21}$ Rezin esaslı fissür örtücü materyalleri renklerine göre, şeffaf, opak ve renkli olarak sınıflandırılırlar. Opak ve renkli fissür örtücü materyallerinin retansiyonları kolay kontrol edilebilir ve aileler tarafından fark edilebilir olduğu için kullanımı sıklıkla tercih edilmektedir. Ebeveynler fissür örtücüyü çocuklarının dişinde rahat bir şekilde görebileceğinden, diş üzerinden fissür örtücü kaybedildiğinde kontrolü kolay sağlanabilmektedir. Şeffaf fissür örtücü materyallerinin ise alt katmanda çürük oluşumunu değerlendirmede faydalı oldukları bildirilmiştir. ${ }^{22}$ Yapılan bir çalışma, fissür örtücü tanımlama hatasının opak rezin örtücü maddesi için sadece \% 1 olduğunu, şeffaf rezin örtücü maddesi için \% 23 olduğunu göstermiştir. ${ }^{23}$

Rezin esaslı örtücü maddeleri (REÖ), polimerizasyon methodlarına göre dört jenerasyonda sınıflandırılır. Birinci jenerasyon REÖ, polimerizasyonu başlatan malzemedeki başlatıcılar üzerindeki ultraviyole ışınlarının etkisiyle polimerize edildi; ancak bu tür, artık kullanılmamaktadır. Nuva-Seal ${ }^{\circledR}$ (LD. Caulk
Co..: Milford, DE, ABD), piyasaya ilk giren örtücü maddesiydi ve ultraviyole ışık kaynağı ile polimerize edilen rezin esaslı bir örtücü maddesi örneğidir. ${ }^{24}$ İkinci jenerasyon fissür örtücüler ultraviyole ışık kaynağına intiyaç duymadan kimyasal olarak polimerize edilmektedir. Bunlar Bis-GMA ve başlatıcı olarak benzoil peroksit içeren birinci kısım ve bis-GMA ve \%5'lik organik amin hızlandırıcı içeren ikinci kısımdan oluşmaktadır. Bu iki kısımın karıştırılmasından sonra genellikle 1-2 dk içerisinde ekzotermik reaksiyon meydana gelir ve sonrasında materyal sertleşmeden hızlı bir şekilde dişe yerleştirilmelidir. Karıştırma işlemi esnasında hava kabarcığı oluşmamasına dikkat edilmelidir, çünkü bunlar fissür örtücü dişe yerleştirildikten sonra örtücü yüzeyinde materyalin başarısını olumsuz etkileyecek pürüzlere ve boşluklara yol açabilir. ${ }^{25}$ Üçüncü jenerasyon fissür örtücü materyalleri içerisine 400-500 nanometre dalga boyunda görünür ışıkla aktive olarak polimerizasyon reaksiyonunu başlatan kamforokinon gibi diketon başlatıcılar ve reaksiyonu hızlandıran alifatik aminler ilave edilmiştir. ${ }^{26}$ Üçüncü jenerasyon fissür örtücüler ikinci jenerasyon fissür örtücülere göre bazı avantajlara sahip oldukları için sıklıkla tercih edilmektedirler. Bu avantajlar arasında, kolay uygulanabilmeleri, yeterli çalışma süresinin olması, hızlı sertleşme, karıştırma işlemi olmadığı için hava boşluğu oluşma riskinin olmaması sayılmaktadır. ${ }^{21}$ Dördüncü jenerasyon flor içeren fissür örtücüler, çürükleri engellemek amacıyla ışıkla sertleşen rezin esaslı fissür örtücüye flüorür salgılayan parçacıkların eklenmesiyle üretilen bir üründür. ${ }^{21}$

Rezin esaslı örtücüler ayrıca viskozitelerine göre (dolduruculu ve doldurucusuz) sınıflandırılabilir. Doldurucu partiküllerin fissür örtücü malzemesine eklenmesinin, klinik sonuçlar üzerinde sadece küçük bir etkiye sahip olduğu bildirilmiştir. Dolduruculu fissür örtücülerin aşınma direnci daha yüksek olmasına rağmen, fissürlere penetre olma yetenekleri düşüktür. Dolduruculu fissür örtücüler genellikle prosedürü gereksiz yere uzatan oklüzal ayarlamalar gerektirir. Öte yandan, doldurucusuz rezin örtücü malzemeleri daha düşük viskoziteye sahiptir ve fissürlere daha iyi penetrasyon ve daha iyi retansiyon sağlarlar. ${ }^{21,27}$

\subsection{CAM IYYONOMER SIMMAN ESASLI} FİSSÜR ÖRTÜCÜLER

Cam iyonomer simanların (CİS) flor salınımları, dişe kimyasal olarak bağlanabilmeleri, Isısal genleşme katsayısının diş sert dokularıyla uyumlu olması, sertleşme sırasında serbest monomer salmamaları, rezinlere oranla daha az büzülmeleri gibi olumlu 
Özelliklerinden dolayı pit ve fissür örtücü olarak kullanılmaları önerilmiştir. ${ }^{28}$ Ayrıca CİS'ların kompozit rezinler kadar estetik olmamaları, suya ve kurumaya eğilimleri, çalışma zamanının kısa olması, aşınma ve kırılma direncinin düşük olması, yüksek oranda mikrosızıntı göstermeleri gibi olumsuz özellikleri de bulunmaktadır. ${ }^{29}$ Cam iyonomer fissür örtücüler, örneğin kısmen sürmüş kalıcı dişlerde ve özellikle de operculum oklüzal yüzeyin distal kısmını kapladığında zor nem kontrolü nedeniyle rezin esaslı örtücü materyali kullanılamadığı zaman geçici örtücü maddesi olarak kullanılabilir. ${ }^{30}$ Bununla birlikte, dişleri izole etmek mümkün değilse, örneğin, uyumlu olmayan hastalar, çocuklar veya surme durumundaki dişlerde, cam iyonomer ortucu malzemeleri tercih edilmelidir. ${ }^{31}$ Geçici bir örtücü maddesi olarak kabul edilir ve daha iyi izolasyon mümkün olduğunda rezin esaslı bir örtücü maddesi ile değiştirilmesi gerekir. ${ }^{31}$

Fissür örtücülerin klinik başarısı uzun dönem retansiyonlarına bağlı olsa da örtücüler zaman içerisinde bütünlüklerini kaybedebilmektedirler. Yapılan pek çok çalışmada CİS'ların retansiyon oranının rezin içerikli olanlara kıyasla daha düşük olduğu bildirilmesine rağmen, pit ve fissürler de çürüğü önlemede etkin oldukları gösterilmiştir. Bu durumun sebebinin klinik olarak fissür örtücünün tamamen kayıp olduğu belirlense bile fissür tabanında Cİs'in az miktarda kalsa dahi mineye flor geçişini sağlayarak remineralizasyona katkı sağlaması olduğu belirtilmiştir. ${ }^{25}$

\subsection{REZİN MODİFİYE CAMİYONOMER ESASLI FİSSÜR ÖRTÜCÜLER}

CİS'ların nem hassasiyeti ve düşük fiziksel özellikleri gibi mevcut olumsuzluklarının giderilmesi için, yapılarına rezin ilave edilerek sertleşme mekanizmaları değiştirilmiş ve 1992 yılında rezin modifiye cam iyonomer simanlar (RMCİS) piyasaya sunulmuştur. Bu restoratif materyaller \%80 cam iyonomer siman ve \%20 rezin esaslı hibrit karışımından oluşmuştur. ${ }^{26,29}$ Ayrıca bu materyaler artmış yüzey sertliği ve uzamış çalışma süresi gibi avantajlara sahiptir. RMCİS'ların toz kızmı floroaluminosilikat cam tozları, likit kısmı ise HEMA, metakrilat grupları, tartarik asit, poliakrilik asit ve $\% 8$ oranında su içermektedir. ${ }^{20}$ RMCİS'ın biyouyumluluğunun içerdiği HEMA'ya bağlı olarak geleneksel CİS'lardan daha düşük olduğu belirtilmiştir. ${ }^{32}$ RMCİS ve geleneksel CİS esaslı fissür örtücülerin karşılaştırıldığı bir çalışmada, RMCİs esaslı fissür örtücülerin retansiyonunun geleneksel Cİs esaslı fissür örtücülerden daha iyi olduğu ancak rezin içerikli fissür örtücüden daha düşük olduğu bildirilmiştir. ${ }^{33}$ Yapılan diğer bir çalışmada RMCİs ile rezin esaslı bir fissür örtücünün yüzey özellikleri, retansiyon ve çürük önleyici özellikleri karşılaştırılmıştır. Çalışma sonucunda 1 yıllık takipte RMCİS'ın adezyonunun, aşınma direncinin, retansiyonunun ve çürük önleyici özelliklerinin rezin esaslı fissür örtücü kadar iyi olduğu gösterilmiştir. Bu nedenle RMCIS'ların rezin esaslı fissür örtücülere alternatif olabileceğini bildirmişlerdir. ${ }^{34}$

\subsection{POLİASIT MODİFIYYE KOMPOZIT REZİN ESASLI FİSSÜR ÖRTÜCÜLER}

Kompomer olarak da adlandırılan, poliasid modifiye rezin esaslı kompozit malzeme, fissür örtücü maddesi olarak da kullanılmıştır. İçeriğinde \%70-80 oranında kompozit rezin, \%20-30 oranında cam iyonomer siman ve \%13 oranında flor bulunmaktadır. PMKR'in fiziksel özellikleri kompozitlere benzerdir ancak kompozitlere göre aşınmaları daha fazla ve kırılma dirençleri daha düşüktür. ${ }^{35}$ PMKR esaslı fissür örtücü materyallerinin retansiyon ve çürük önleme özelliklerinin değerlendirildiği klinik bir çalışmada, retansiyonlarının düşük olduğu ancak çürük önlemede başarılı oldukları bildirilmiştir. ${ }^{36}$ Yapılan diğer bir çalışmada, PMKR esaslı fissür örtücülerden flor salınımının CİS esaslı fissür örtücülerden daha düşük olduğu saptanmıştır. ${ }^{37}$

\subsection{ORMOSER ESASLI FİSSÜR ÖRTÜCÜLER}

Ormoserler (organically modified ceramic), biyouyumlu ve polimerizasyon büzülmesinin önemli ölçüde azaltıldığı, karbon yerine uzun "back bone" silikondan oluşan bir materyal olarak tanıtılmışlardır. ${ }^{38}$ Monomer molekülünün büyük boyutu sayesinde bu sistem polimerizasyon büzülmesini ve aşınmayı azaltıp monomer salınımın da azalmaya sebep olduğundan kompozit restorasyonlar için matris olarak kullanılabilmektedir. Bunun sebebi polimerizasyon büzülmesini azaltmak, biyouyumluluğu, abrazyon dayanımını ve marjinal adaptasyonu artırmaktır. Ancak laboratuvar çalışmaların da bu özellikler doğrulanmamıştır. ${ }^{39}$ Yapılan bir çalışmada Cís ve ormoser esaslı fissür örtücüler retansiyon, marjinal bütünlük ve sekonder çürük oluşumu açısından karşılaştırılmıştır. Çalışma sonucunda her iki materyalde retansiyon ve kenar bütünlüğü açısından benzer sonuçlar elde edilmiş ve Cís esaslı fissür örtücünün çürük önleyici etkisi diğerlerinden daha yüksek bulunmuştur. ${ }^{40}$

\subsection{GİOMER ESASLI FİSSÜR ÖRTÜCÜLER}

Giomer, reaksiyona girmiş cam doldurucular (pre-reacted glass ionomer fillers-PRG) içeren rezin matriksten oluşan, flor salabilen ve ışıkla sertleşen restoratif bir materyal olarak tanıtılmıştır. Giomer esasIı fissür örtücüler, asitle pürüzlendirme ve yıkama 
işlemi olmadan self etch primer uygulamasının ardından kullanılabilmektedir. Böylece asitle pürüzlendirme sırasında ortaya çıkan olumsuzlukları ortadan kaldırırlar ve klinik uygulama süresini kısaltarak hem hasta hem de hekim için zaman tasarrufu sağlarlar. Ancak yapılan bir çalışmada, asit uygulama basamağı yapılmadan gerçekleştirilen giomer esaslı fissür örtücülerin mikrosızıntı ve bağlanma dayanımlarının, geleneksel rezin esaslı sistemlerden ve asitle birlikte uygulandıklarında elde edilen değerlerden anlamlı derecede daha düşük olduğu belirtilmiştir. ${ }^{41}$

Yapılan bir çalışmada, rezin esaslı, rezin modifiye, cam iyonomer içerikli ve giomer esası fissür örtücülerin süt dişlerinde yaratılan demineralizasyonu inhibe edici etkileri değerlendirilmiştir. Tüm örtücü tiplerinin demineralizasyonu inhibe ettiği fakat mineral kaybı ve lezyon derinliği açısından en başarılı sonuçları rezin modifiye cam iyonomer içerikli fissür örtücünün sergilediği, bunu giomer esasl, daha sonra da rezin esaslı fissür örtücülerin takip ettiği bildirilmiştir. Bu sonuçlara ek olarak, minede flor seviyeleri ölçüldüğünde yine en yüksek verileri rezin modifiye cam iyonomer içerikli fissür örtücünün gösterdiği, en düşük değerlerin ise giomer esaslı fissür örtücüden elde edildiği gösterilmiştir. ${ }^{42}$ Yapılan diğer bir çalışmada, florid içerikli iki farklı rezin esaslı fissür örtücü, giomer bazlı örtücü ve geleneksel cam iyonomer simanın kümülatif florid salımını karşılaştıııııışıı. Çalışma sonucunda, en düşük florid salımının giomer grubunda olduğunu, materyallerin 5 günlük uygulama sonrası reşarj kapasitelerinin incelendiği aşamada ise giomer bazlı örtücülerin rezin esaslı örtücülerden daha yüksek fakat geleneksel cam iyonomer simandan çok daha düşük seviyede flor salımı gerçekleştirdiğini bildirmişlerdir. ${ }^{43}$

3.7. CAM KARBOMER ESASLI FİSSÜR ÖRTÜCÜLER

Karbomerler, karbonize nanopartiküller içeren cam iyonomer yapıda simanlardır. Ayrıca nano boyutlu toz partikülleri ve floroapatit içermeleri nedeniyle cam iyonomer simanlardan ayrlırlar. Deneysel olarak geleneksel Cís içerisine nanoboyuttaki partiküller ilave edildiğinde materyalin dayanıkılık, aşınma direnci, bağlanma dayanımı ve remineralizasyon kapasitesi gibi mekanik özelliklerinin arttığı belirtilmiştir. ${ }^{44}$ Cam karbomerler, mine veya dentine herhangi bir işlem uygulanmadan bağlanabilirler. Cam karbomerlere Cİ'lardan farklı olarak sertleşme reaksiyonu sırasında ISı uygulaması yapılmalıdır. Isı uygulaması ile sertleşme reaksiyonu hızlanmakta, basma dayanımını artmakta ve mikrosızıntı azalmaktadır. Cam karbomerlerin flor salınımı ve yeniden yüklenebilme gibi özellikleri de bulunmaktadır. Cam karbomerlerin çürük önleme ve florapatit oluşturarak remineralizasyona katkı sağlama gibi özelliklerinin olmasının yanında, Bisfenol-A ve organik çözücüler gibi sağlığa zarar verme riski olan materyalleri içermemesi de bir avantajı olarak düşünülebilmektedir. ${ }^{45}$

Yapılan bir in vitro çalışmada cam karbomer esaslı fissür örtücünün farklı pH'larda çözünürlükleri değerlendirilmiştir. Cam karbomerlerin geleneksel cam iyonomerden daha az cözündüğü ve mikrosızıntı açısından aralarında bir fark olmadığı gösterilmiştir. Bu nedenle özellikle nem kontrolü sağlanmasının zor olduğu tam olarak sürmemiş dişlerdeki fissürlerinin tedavisinde cam karbomer kullanımının alternatif olabileceği belirtilmiştir. ${ }^{46}$ Yapılan klinik bir çalışmada, yüksek viskoziteli cam iyonomer esaslı, cam karbomer ve rezin esaslı fissür örtücülerin 2 yıllık takip sonrasındaki retansiyon oranları karşılaştırımış ve cam karbomer esaslı örtücülerin retansiyon oranlarının diğer gruplara göre oldukça düşük olduğu belirtilmiştir. ${ }^{47}$ Yapılan diğer bir in-vitro çalışmada ise; cam karbomer esaslı, CPP-ACP ilaveli ve geleneksel cam iyonomer esaslı fissür örtücüler karşılaştırımış ve cam karbomer esaslı materyalin mikrosızıntı, penetrasyon kabiliyeti, bağlanma dayanımı gibi fiziksel özellikler açısından diğer iki materyalden daha başarısız olduğu bildirilmiştir. Çalışmada, cam karbomer esaslı materyalin sadece florid salımı açısından diğer materyallerden daha başarılı olduğu belirtilmiştir. Cam karbomerin yetersiz mikromekanik retansiyonu ve penetrasyon kabiliyetinin, yüzey hazırlığı sırasındaki düşük asitleme kapasitesi ve muhtemel düşük akışkanlı̆ı ile ilişkili olabileceği bildirilmiştir. ${ }^{48}$

\section{FARKLI ÖRTÜCÜ MATERYALLERİNİN}

\section{RETANSIYYONU}

Önceden, örtücülerin çürük önlenmedeki etkilerini araştıırken, örtücü uygulanmış dişler ile örtücü uygulanmamış kontrol grubu dişlerin karşılaştırıldığı yarım ağızlı çalışma tasarımları kullanıımıştır. 1980'lerde pit ve fissür örtücü maddelerinin koruyucu rolü belirlendikten sonra, bu tür bir çalışma tasarımı etik dışı olmuştur. Başka bir deyişle, çürükten korumada örtücünün etkinliğinin kanıtlanmasının ardından kontrol olarak örtücü maddesi uygulanmayan dişlerin bırakılması artık kabul edilemezdi. ${ }^{49}$ Çoğu çalışmada retansiyon oranını "bozulmamış örtücü maddesi", "kısmi kayıp" ve "tamamen kayıp" olarak sınıflandırıımışıı. ${ }^{50}$

Yapılan bir meta-analiz, farklı takip zamanlarında ve farklı türdeki malzemelerle ilgili pit ve fissür örtücü maddelerinin klinik retansiyon oranlarını araştır- 
mıştır. Rezin esaslı örtücü maddeleri en iyi retansiyon oranlarını göstermiştir: Işıkla polimerize, otopolimerize ve flor içeren rezin esaslı örtücü maddeleri için beş yıllık retansiyon oranları sırasıyla \% 83,8, \% 64,7 ve $\%$ 69,9 olduğu bildirilmiştir. Diğer taraftan cam iyonomer esaslı fissür örtücü malzemeleri için, beş yıllık gözlem süresinde \% 5,2 retansiyon oranı bildirilmiştir. Ayrıca, poliasid modifiye rezin örtücü malzemeleri düşük retansiyon oranları göstermiştir. ${ }^{49}$

Dolduruculu ve doldurucusuz rezin esaslı örtücülerin retansiyon oranlarını karşılaştıran bir çalışma, rezin esaslı dolduruculu örtücü maddesi Helioseal $F$ (Ivoclar Vivadent, Schaan, Lihtenştayn) ve rezin esaslı doldurucusuz örtücü maddesi Clinpro'nun (3M ESPE, Saint Paul, MN, ABD) retansiyonları değerlendirmiştir. Doldurucusuz rezin esaslı örtücü maddelerinin, 12 aylık takipte, dolduruculu rezin esaslı örtücü maddelerine kıyasla biraz daha yüksek retansiyon oranları gösterdiği sonucuna varmışlardır. Doldurucu maddesi olmayan örtücüler, daha düşük viskozitelerinden dolayı doldurucu parçacıkları içeren örtücüler ile karşılaştırıldığında, fissürlere daha iyi nüfuz etmiş görünmektedir. $^{27}$

Amerikan Diş Hekimliği Akademisi'nin işbirliğiyle Amerikan Diş hekimliği Birliği'nin önerilerinin son güncellenmesi, cam iyonomer örtücü maddesi retansiyon kaybının rezin esaslı örtücüye göre beş kat, rezin modifiye cam iyonomer esaslı örtücü malzemesine göre 3 kat daha yüksek olduğunu bildirmiştir. Buradaki fark istatistiksel olarak anlamlıdır, ancak kanıtların kalitesi çok düşük olarak değerlendirilmiştir. ${ }^{31}$

\section{SÜT DİşLEİNDE ÖRTÜcü UYGULAMASI}

Çürük risk değerlendirmesine dayanarak, süt dişlerinin fissür anatomisi veya hasta risk faktörleri nedeniyle risk altında olduğu düşünülebilir ve bu nedenle örtücü uygulamasından yararlanabilir. ${ }^{10} \mathrm{Bu}$ nedenle, süt dişlerinde pit ve fissür örtücüler, bu dişlerin derin retansiyonlu veya lekeli pit ve fissürleri ile pit ve fissürlerde dekalsifikasyon belirtisi var ise veya çocuğun kontralateral süt molar veya diğer süt dişlerinde çürük veya restorasyon var ise endikedir. Örtücüler özellikle tıbbi, fiziksel veya zihinsel engelli çocuklar ve gençler için düşünülmelidir. ${ }^{51}$

Pit ve fissür örtücü maddelerinin süt azı dişlerinde bir yılda \% 74 ila \% 96.3 oranında ve 2,8 yılda $\%$ 70.6-76.5 oranında retantif olduğu tespit edilmiştir. ${ }^{52}$ Bununla birlikte, çoğu örtücü çalışmasının odak noktası, daimi molarların oklüzal yüzeyleridir ve fissür örtücü malzemelerinin süt molarlar da kullanılmasını destekleyen kanitlar halen yetersizdir. ${ }^{31}$ Rathnam ve
Madan, diş kliniğinde bilmediği bir düzen sunulduğunda çocuğun yaşı, işbirliği ve davranışları gibi faktörler nedeniyle süt dişleri üzerinde klinik çalışmalar yapmanın zor olduğunu belirtmektedir. ${ }^{53}$ Klinik prosedürü basitleştirmek ve fissür örtücü uygulamasını küçük çocuklar için daha kabul edilebilir kılmak ve tükürük kontaminasyon olasılığını azaltmak için daha kısa bir asitleme süresi kullanılabilir. Birkaç çalışma asitleme süresinin uzunluğunun örtücü maddesi retansiyonu üzerinde minimal bir etkiye sahip olduğunu göstermiştir. ${ }^{54}$ Küçük çocuklarda prosedür süresini kısaltmak için kullanılabilecek bir başka önlem, geleneksel asitle aşındırma tekniğine bir alternatif olarak self etch bonding ajanların kullanılmasıdır. Çeşitli çalışmalar, geleneksel asit aşındırma ile karşılaştırıldığında self etch bonding ajanlar kullanıldığında, süt dişlerinde anlamlı derecede düşük bir örtücü retansiyon oranı göstermiştir. ${ }^{55}$ Dahası, çalışmalar, tükürük kontaminasyonu beklendiğinde cam iyonomer örtücü maddesinin kullanılmasının iyi bir ara seçenek olabileceğini göstermiştir, çünkü rezin esaslı örtücü maddelerine kıyasla neme daha fazla toleransı vardır. Bununla birlikte, süt dişlerinde cam iyonomer örtücü maddesi kullanımı ile ilgili çalışmalar çok sınırlıdır ve bu nedenle bu alanda daha fazla araştırmaya intiyaç duyulmaktadır. ${ }^{56}$

\section{KAVİTASYON OLMAMIŞ ÇÜRÜK LEZYONLARINA ÖRTÜCÜ UYGULANMASI}

Kavitasyonsuz çürük lezyonları, herhangi bir kavitasyon olmadan başlangıç çürük lezyonu gelişimini ifade eder. Makroskobik bozulma meydana gelmeden önce demineralizasyon nedeniyle renk, yüzey yapısı ve parlaklıktaki değişim ile tanımlanır. Remineralizasyon ve demineralizasyon arasındaki dengeyi yeniden kurmak, çürüğün ilerlemesini durdurabilir. ${ }^{1}$ Kavitasyonsuz oklüzal çürük tanısı koymadaki zorluk nedeniyle, diş hekimleri çürüğü yanlışlıkla yıllar boyunca örtücü ile kapatmış olabilirler. Birçok çalışma, çürüğün ilerlemesinin örtücü malzemeleri altında yavaşlatıldığını veya durduğunu göstermektedir. Bakteriyel beslemenin engellenmesi, örtücü malzemeleri altında gözlemlenen çürük ilerlemesinin durdurmasının açıklaması olabilir. ${ }^{57}$ Bir meta-analiz, örtücü uygulanmış daimi dişler altında çürüğün ilerlemesini incelemiştir. Analize 840 dişi temsil eden altı çalışma dahil edilmiştir. Dört çalışmada kavitasyon oluşmamış lezyonlara örtücü uygulanmış ve diğer iki çalışmada restorasyonlar üzerine örtücü maddesi uygulanmıştır. Kavitasyon oluşmamış çürük lezyonlarının ortalama yıllık yüzdesi örtücü uygulanmış dişler için \% 2,6 ve örtücü uygulanmamış dişler için \% 12,6 olduğu belirtilmiştir. Bu, kavitasyon oluşmamış lezyonlara örtücü uygulanma- 
sının çürüklerde ilerlemeyi azaltmada etkili olduğunu göstermiştir. ${ }^{58}$ Bir başka randomize, kontrollü çalışma, örtücüler altındaki kavitasyonsuz dentin lezyonlarının ilerlemesini değerlendirmiştir. Örtücü uygulanmış grupta (deney grubu) ve örtücü uygulanmamış grupta (kontrol grubu) 30 adet molar diş çalışmaya dahil edilmiştir. Sonuçlar iki grup arasında dikkate değer bir fark göstermiştir; Sekiz aylık takipte kontrol grubundaki 26 molardan 25'i (\% 96.1) çürük gelişimi göstermiştir. 12 aylık takipte, deney grubundaki 26 molardan üçünde (\% 11.5) çürük gelişimi bildirilmiştir. Bu azı dişlerinin kısmi veya tam örtücü kaybına sahip olduğu gözlenmiştir. Böylece kısmi ve tam örtücü maddesi kaybının, çürük lezyonlarının önlenmesindeki etkinliği sınırladığı sonucuna varımıştır. ${ }^{59}$ Dahası, son zamanlarda yapılan kritik bir değerlendirme, başlangıç oklüzal çürük lezyonlarına örtücü uygulanması ile ilgili klinik çalışmalardan kanıtlar sunmuş ve çürük lezyonlarının iyi örtücü uygulanmış yüzeyler altında ilerlemediği sonucuna varmıştır. ${ }^{60}$

Yakın tarihli bir sistematik derlemede, kavitasyon oluşmamış dentin lezyonlarına örtücü uygulanması desteklenmiş ve rezin esaslı örtücü uygulamasının kavitasyon olmamış dentin lezyonlarının ilerlemesini önleyebildiği, cam iyonomer örtücü maddelerinin ise düşük retansiyon oranları gösterdiği ve çürük ilerlemesini durduramadığı sonucuna varılmıştır. ${ }^{61}$ Mevcut kanıtlar ve ADA Konseyi'nin önerileri ve AAPD kılavuzları, Avrupa'daki çocuk ve genç erişkinlerde kavitasyon oluşmamış erken çürük lezyonlarına örtücü uygulanmasını desteklemektedir. Bununla birlikte, örtücü maddelerinin düzenli olarak takip edilmesi ve onarılırsa daha etkili oldukları bildirilmiştir. ${ }^{52,62}$

\section{REZIN ESASLI FİSSÜR ÖRTÜCÜLERÍN YERLEŞTİRİLME TEKNİKLERİ}

"İnvaziv teknik", oklüzal yüzeydeki fissürleri derin ve dar olan dişlerde fissürlerdeki organik materyal, plak ve ince yüzeyel prizmasız mine tabakasını elimine etmek için pit ve fissürlerin çapı 0.5-0.6 mm olan alev uçlu bir frezle aşındırılıp genişletildikten sonra fissür örtücü uygulama yöntemidir. Bu teknik sayesinde asit ve örtücüler fissürlerin daha derin bölgelerine penetre olabilmekte ve mine yüzey alanını artmaktadır. ${ }^{63}$ İnvaziv yaklaşımın organik materyaller ve prizmasız tabakayı elimine ettiği böylece, fissür örtücünün penetrasyonunu artırdığı ve buna bağlı olarak da mikrosızıntı riskini azalttığı belirtilmektedir. ${ }^{62}$ Fissür örtücü uygulaması öncesinde invaziv tekniğin kullanılması, retansiyonu artırmanın yanı sıra diş hekimlerine fissür örtücü uygularken özellikle klinik çürük teşhisinin zor olduğu fissürlerde daha güvenle çalışma imkanı da sağlamaktadır. Bazı araştırmacılar, çürük teşhisi konusunda şüpheye düşüldüğünde invaziv tekniğin kullanılmasını savunmuştur. ${ }^{62,64}$

"Non invaziv teknik"de ise diş üzerinde bulunan debris uzaklaştırıldıktan sonra, diş yüzeyinde herhangi bir invaziv işlem yapılmadan fissür örtücü uygulama yöntemidir. ${ }^{65}$ İnvaziv ve non-invaziv teknikler arasında seçim yapmak tartışmalı bir konudur. Yapılan bir çalışmada, invaziv ve noninvaziv yöntemle uygulanan fissür örtücülerin mikrosızıntı değerleri arasındaki fark anlamlı bulunmamıştır. ${ }^{63}$ Sağılılı bir dişin fissürlerini yalnızca genişletmek amacıyla uzaklaştırmak anlamına gelen invaziv yöntemin, fissür sisteminin dengesini bozduğu ve çocuğun döner aletler ya da air-abrazyona gereksiz şekilde maruz kalmasına yol açtığı düşünülmektedir. Ayrıca dişlerin yaşam boyunca tekrar tekrar restore edilmesinin gerekmesi de yöntemin bir diğer dezavantajıdır. Bu bilgiler varlığında, yeterli bağlanma sağlamak için fissürlerdeki organik debrisin uzaklaştırılması gerektiği, ancak sağlıklı diş dokusunun döner aletler veya air-abrazyon gibi yöntemlerle uzaklaştırımasının gereksiz ve istenmeyen bir işlem olduğu sonucuna varılmıştır. ${ }^{66}$

Üreticilerin fissür örtücü maddesi kullanımına yönelik talimatlarının çoğu, asitle aşındırma işleminden önce pit ve fissürlerin dikkatlice temizlenmesini önerir. Bir çalışma, iki ila beş yıllık takiplerde diş fırçası ile el aleti profilaksisi arasında örtücü retansiyonu açısından hiçbir fark olmadığını bildirmiştir. ${ }^{67}$ Bazı üreticilerin talimatları, örtücü maddesi yerleştirilmesinden önce florür kullanımının asit içerisindeki mine çözünürlüğünü azalttığı, böylece minenin düzgün şekilde aşındırılmasını engellediğini için kontrendike olduğunu belirtmiştir. Bununla birlikte, Warren ve ark., 18 aylık bir süre boyunca florür işleminden önce ve sonra iki örtücü maddesinin örtücü retansiyonunu karşılaştırdıkları bir çalışmada; ışıkla polimerize olan rezin esaslı örtücüler kullanıldığında florlanmış dişlerde anlamlı derecede daha yüksek bir retansiyon olduğunu ve autopolimerize rezin esaslı örtücüler kullanıldığında retansiyonda anlamlı bir fark olmadığını bildirmişlerdir. Bu, örtücü maddesinin örtücü yerleştirilmesinden hemen önce florür uygulamasından zarar görmeyebileceğini göstermiştir. ${ }^{68}$ Yapılan bir diğer çalışmada, iki farklı rezin içerikli fissür örtücünün (Fissurit FX, Smart Seal) klinik başarısına, iki farklı polisaj tekniğinin (air-polishing, polisaj pastası) etkinlikleri karşılaştırılmıştır. Çalışma sonucunda iki farklı polisaj yöntemi ile uygulanan her iki fissür örtücüde de kabul edilebilir düzeyde klinik başarı sağlandığı belirtilmiştir. Ayrıca retansiyon açısından materyaller arasında ve proflaksi yöntemlerinin 
arasında istatistiksel olarak anlamlı bir fark bulunmamıştır. ${ }^{69}$

Rezin örtücü yerleştirme sırasında yeterli nem izolasyonu, örtücü uygulamasındaki en kritik aşamadır. Asitlenmiş mine tükürük proteinlerine 0,5 sn kadar kısa sürede maruz kalırsa, kontamine olabilir. Bu durumda, yeniden asitleme gereklidir. ${ }^{31}$ Rubber dam kullanılması, optimum nem kontrolünü sağlamak için ideal bir yoldur. Pamuklu ruloların ve tükürük emicinin kullanılması da geçerli bir yöntemdir. ${ }^{66}$ Sistematik bir derleme, iki elle izolasyonla karşılaştırıldığında dört elle izolasyonun, yüzey temizleme yöntemi gibi diğer faktörler kontrol edildiğinde örtücü retansiyonu \% 9 oranında artırdığını belirtmiştir. Dört elle kullanılan tekniğin kullanılmasının, örtücü yerleştirilmesini kolaylaştırdığı ve aynı zamanda daha iyi retansiyon ile de ilişkili olduğu bildirilmiştir. ${ }^{58}$

İlk olarak 1955 yılında Buonocore tarafından aşındırma için kullanılan fosforik asit konsantrasyonu \% 85 idi, ancak daha sonra erken klinik çalışmalarında bu oran $\% 50$ 'ye düşürülmüştür. ${ }^{11}$ Günümüzde $\% 35$ ve \% 37 yaygın olarak kullanılan konsantrasyonlardır. ${ }^{70}$ Süt dişleri mine aşındırma süresi için erken öneriler, daimi mine için kabul edilen sürenin iki katı, yani süt minesi için $120 \mathrm{~s}$ ve daimi mine için $60 \mathrm{~s}$ idi. ${ }^{22}$ Yapılan bir çalışmada, aşındırma süresinin uzunluğunun örtücü maddesi retansiyonu üzerinde çok az etkisi olduğunu göstermiştir. 15, 30, 45 ve 60 s farklı aşındırma süreleri olan bir yıllık takipten sonra fissür örtücü maddelerinin süt veya daimi azı dişlerinde retansiyonu bakımından anlamlı bir fark bulunmamıştır. ${ }^{54} 30$ saniye durulama süresi ve dişi 15 saniye kurutmak, tüm asit eter kalıntılarını uzaklaştırmak ve karakteristik kireçli beyaz soğuk mine görünümü elde etmek için yeterli olmaktadır. ${ }^{24}$

Ayrıca, literatür, air abrazyon ve bir frez ile modifikasyon (enameloplasty) gibi çeşitli mekanik mine hazırlama formlarının kullanılması yerine, bonding ajanların kullanımını içeren ilave teknikler önermektedir.( Örtücü maddesi altında bir yapıştırıcı madde kullanılması fikri, 1993 yılında Feigal ve arkadaşları tarafından, örtücü maddesinin nemli bir ortamda uygulandığında yapışma kuvvetine yardımcı olmak için hidrofilik yapıştırma malzemeleri kullanmalarından gelmektedir. $^{71}$ Çeşitli çalışmalar, örtücü maddesi uygulamasından önce bir bonding ajan kullanımını değerlendirmiştir. Randomize kontrollü bir çalışma, örtücü maddeleri altında kullanıldığında dördüncü nesil (üç aşamalı etch and rise) ve beşinci nesil (iki aşamalı etch and rise) adhezivler karşılaştırmıştır. İki aşamalı adhezivlerin oklüzal yüzeylere uygulandığında örtücü kaybı riskini yarı yarıya düşürdüğünü bulmuşlardır. ${ }^{72}$ Son zamanlarda yapılan bir sistematik derleme, selfetch adheziv sistemleri (altıncı veya yedinci nesil) ile, etch ve rise adheziv sistemleri (dördüncü ve beşinci kuşak) ile uygulanmış örtücü maddelerinin retansiyon oranını karşılaştırmıştır. Beş çalışma dahil edilmiş: bunun üç çalışması, etch and rise adheziv sistemlerinin self etch adheziv sistemlerinden önemli ölçüde daha iyi bir retansiyona sahip olduğunu göstermiştir. Diğer iki çalışma ise, iki adheziv sistem arasında anlamlı bir fark olmadığını göstermiştir. Sistematik derleme, oklüzal fissür örtücü maddelerinin retansiyonunun, etch ve rise adheziv sistemiyle uygulandığında, self etch adheziv sisteme göre daha yüksek olduğu sonucuna varmıştır. ${ }^{73}$ Yapilan bir diger calismada, altıncı (Adper promt), yedinci (Optibond) ve sekizinci (Futurabond Dual Cure) kuşak bonding ajanlar kullanılarak uygulanan pit ve fissür ortucunun retansiyonu değerlendirmis ve 3 ve 6 ay sonra gruplar arasında istatistiksel olarak anlamlı bir fark olmadığı bulunmustur. Bu çalışma, pit ve fissur ortucu uygulamasindan önce bonding ajan kullanılmasının, bonding ajan kullanilmadan uygulanan pit ve fissur ortuculere klyasla, ortucu maddesinin retansiyonuna yardımcı olmadığı sonucuna varmıştır. Ortucu maddelerinin etkinliği, retansiyonlariyla doğrudan iliskilidir ve bu uygulama prosedürlerine bağııdır. ${ }^{74}$

Özetle, yukarıda belirtilen çalışmalar, fissür örtücü uygulamasından önce adheziv sistemlerin kullanılmasının, penetrasyonu ve retansiyon oranının arttırılması üzerinde olumlu bir etkisi olduğunu göstermiştir. Ayrı bir asit aşındırma basamağı (dördüncü ve beşinci kuşaklar) içeren bonding ajanların kullanılmasının, self etch adhezivlerden (altıncı ve yedinci kuşaklar) daha iyi bir örtücü maddesi retansiyonu sağladığı görülmektedir. Etch and rise adheziv sistemlerin, mine yüzeyine self etch adheziv sistemlerinden daha iyi nüfuz ettiği ve bunun da daha iyi bir bağlanma kuvvetine neden olduğu düşünülebilir. ${ }^{31}$ Amerikan Diş hekimleri Birliği ve Amerikan Pediatrik Diş Hekimliği Akademisi tarafından yapılan kanıta dayalı 2008 raporu, daha iyi örtücü retansiyonu sağlamak için örtücü uygulamadan önce adheziv sistemlerinin kullanılmasını desteklemektedir. ${ }^{31,52}$

\section{YERLESTTİRİLMEDEN SONRA FİSSÜR ÖRTÜCÜNÜN DEĞERLENDİRİLMESİ}

Fissür örtücü maddesi sertleştirildikten sonra ve izolasyon malzemesinin çıkarılmasından önce, klinisyen fissür örtücü de boşluk, kabarcık veya eksik malzeme olup olmadığı açısından örtücüyü incelemelidir. Örtücü maddesinin düşmemesi için sond kullanılarak örtücü malzemesinin retansiyonu da kontrol edil- 
melidir. Örtücü maddesi kontrol sırasında düşmüşse, fissürler, örtücü malzemesinin düşmesine neden olabilecek kalan yiyecek kalıntıları açısından tekrar kontrol edilmelidir. Diş tekrar asitlenmeli ve yeni bir örtücü malzemesi uygulanmalıdır. ${ }^{51}$

\section{TAKİP (YENİDEN ÇAĞIRMA VE ONARIM)}

Pit ve fissür örtücünün uzun vadeli başarısı, malzemenin sağlam mekanik bağlanmasına bağlı olduğundan, düzenli kontrol gereklidir. Daimi molarlarda ortalama örtücü kaybı yılda yüzde beş ila on arasındadır. ${ }^{75}$ Bu nedenle düzenli örtücü takibi verimliliği en üst düzeye çıkarmak, marjinal bütünlüğü korumak ve optimum örtücü maddesi tarafından verilen korumayı sağlamak için gereklidir. ${ }^{31}$ Bir çalışma, on yıl boyunca 8000'den fazla örtücü maddesini değerlendirmiştir; Yazarlar, yıllık bir geri çağırma ve onarım programının dahil edilmesinden dolayı sekiz ila on yıl arasında örtücü maddesi başarı oranının yüksek olduğunu bildirmişlerdir. Yeniden örtücüye gerek duymayan tam örtücü retaniyon oranının ise on yılda $\% 41$ olduğunu bildirmişlerdir. Örtücü maddelerinin tam retansiyonu görsel, dokunsal ve radyografik olarak kontrol edilebilir. ${ }^{76}$

Kısmen kaybolan örtücü maddesinin, besinleri hapseden ve sonunda çürüğe yol açan keskin kenar boşlukları bırakabileceği konusunda endişeler vardır. ${ }^{75}$ Daha önce örtücü uygulanmış dişlerde tamamen veya kısmen kaybolan örtücü maddesi ile çürük oluşma riskinin hiç örtücü uygulanmamış dişlerdeki riski aşıp aşmadığını değerlendirmeyi amaçlayan ilginç bir sistematik derleme yapılmışır. Yedi çalışma dahil edilmiştir ve katııımcılar 5-14 yaşları arasından seçilmiştir. Dört yıllık bir takip süresinin ardından daha önce örtücü uygulanmış dişlerde çürük gelişme riskinin, hiç örtücü uygulanmamış dişlerdekine eşit veya daha az olduğu bulunmuş̧tur. Başka bir deyişle, kısmi veya tam örtücü kaybı olan dişlerin, hiç örtücü uygulanmamış dişlere kıyasla daha fazla diş çürüğü riski altında olmadığı belirtilmiştir. $\mathrm{Bu}$, uygulayıcının örtücü malzemelerinin uygulama tekniği ile daha az dikkatli olmaları gerektiği veya yerleştirme sonrası değerlendirme ve bakımları yapmamaları anlamına gelmemektedir. ${ }^{77}$

\section{0.ÖSTROJENITTE}

Bisfenol-A (BPA), rezin kompozit restorasyonlarında ve rezin esası örtücü maddelerinde kullanılan en yaygın monomerler olan bisfenol-a dimetakrilat (BisDMA) ve bisfenol-bir glisidil dimetakrilatın (Bis-DMA) öncü kimyasal bileşenidir. Potansiyel üreme ve gelişimsel insan toksisitesine sahip östrojenik özelliği ile bilinir. BPA, monomerlerde ham madde olarak değil, bazen hidrolize edilebilen ve tükürükte bulunan BPA türevleri olarak bulunur. ${ }^{78}$ Sistematik bir derlemede, rezin esaslı örtücü yerleştirilmesinden hemen veya bir saat sonra toplanan tükürük örneklerinde yüksek BPA düzeylerinin bulunduğu bildirilmişțir. İdrar örneklerinde de yüksek BPA seviyeleri tespit edilmiştir. ${ }^{79}$ Bununla birlikte, Amerikan Diş Hekimliği Birliği ve Amerikan Pediatrik Diş Hekimliği Akademisi tarafından hazırlanan bir rapor, örtücü maddesi yerleştirilmesinden sonra yan etkilerin oluştuğunu desteklememiştir ve BPA etkisini küçük bir geçici etki olarak tanımlamışıı. ${ }^{31}$ Bazı çalışmalar, örtücü yüzeyinin derhal temizlenmesi veya örtücü yüzeyinin dış katmanında mevcut olan reaksiyona girmemiş monomerin azaltılması için oksijen inhibisyon katmanının çıkarılmasına yönelik teknikler bildirmiştir. $\mathrm{Bu}$, potansiyel BPA maruziyetini azaltmak için bir pomza veya döner alette bir lastik kullanılarak yapılabilir..$^{79}$

\section{SONUÇ}

Fissür örtücüler, süt ve daimi dişlerde pit ve fissür çürüklerinin önlenmesinde etkili bir araçtır. Bu nedenle diş hekimleri, fissür örtücü maddelerini, çürük riski yüksek olan hastalarda diğer önleyici tedbirlerle birlikte kullanmaya teşvik edilmelidir. Örtücü maddesi seçimi, hastanın yaşına, çocuğun davranışlarına ve diş sürme zamanına bağılıı. Kavitasyon olmamış başlangıç çürük lezyonlarıyla gelen dişlerde başlangıç çürüğünün ilerlemesini önlemek için örtücü uygulamasından da faydalanabilir. Fissür örtücü uygulaması, nem kontrollü bir ortamda yapılması gereken hassas bir prosedürdür. Takip esastır ve gerektiğinde örtücü maddelerinin tekrar uygulanması tedavinin etkinliğini en üst düzeye çıkarmak için önemlidir.

NOT: Çalışmada herhangi bir yazar, kurum ya da kuruluş ile çıkar çatışması içerisinde bulunmamaktadır. Makale daha önce hiçbir yerde yayınlanmamış ve yayınlanmak üzere işlem görmemektedir

\section{KAYNAKLAR}

1. Young DA, Nový BB, Zeller GG, Hale R, Hart TC, et al. The American Dental Association Caries Classification System for Clinical Practice: A Report of the American Dental Association Council on Scientific Affairs.J Am Dent Assoc 2015;146:79-86.

2. Petersen PE. World Health Organization Global Policy for Improvement of Oral Health-World Health Assembly 2007. Int Dent J 2008;58:115-21.

3. Küçükyılmaz E, Akçay M. Cam İyonomer Esaslı Fissür Örtücüler. Turkiye Klin J Pediatr Dent Special Topics. 2017;3:165-74. 
4. Jurić H. Current Possibilities in Occlusal Caries Management. Acta Med Academic 2013;42:216.

5. Kitchens $\mathrm{DH}$. The Economics of Pit and Fissure Sealants in Preventive Dentistry: A Review. J Contemp Dent Pract 2005;6:95-103.

6. Simonsen RJ. Clinical Applications of the Acid Etch Technique: Quintessence Publishing (IL); 1978.

7. Hunter J. A Practical Treatise on the Disease of the Teeth: Johnson; 1778.

8. Wilson I. Preventive Dentistry. Am J Dent Sci 1895;29:10.

9. Hyatt TP. A Statistical Study of the Location of Dental Caries Shows the Practical Value of Prophylactic Odontotomy. Dent Digest 1928; 34:23543.

10. Feigal RJ, Donly KJ. The Use of Pit and Fissure Sealants. Pediatr Dent . 2006;28:143-50.

11. Buonocore MG. A Simple Method of Increasing the Adhesion of Acrylic Filling Materials to Enamel Surfaces. J Dent Res . 1955;34:849-53.

12. Cueto EI, Buonocore MG. Sealing of Pits and Fissures with an Adhesive Resin: Its Use in Caries Prevention. J Am Dent Assoc 1967;75:121-28.

13. Boudreau GE, Jerge CR. The Efficacy of Sealant Treatment in the Prevention of Pit and Fissure Dental Caries: A Review and Interpretation of the Literature. J Am Dent Assoc 1976;92:383-87.

14. Wilson AD, Kent B. The Glass-Ionomer Cement, a New Translucent Dental Filling Material. J Appl Chem Biotechnol 1971;21:313.

15. McLean J, Wilson A. Fissure Sealing and Filling with an Adhesive Glass-Ionomer Cement. Br Dent J 1974;136:269.

16. Gungor H, Altay N, Alpar R. Clinical Evaluation of a Polyacid-Modified Resin Composite-Based Fissure Sealant: Two-Year Results. Operative DentistryUniversity Of Washington-. 2004;29:254-60.

17. Bowen RL. Method of Preparing a Monomer Having Phenoxy and Methacrylate Groups Linked by Hydroxy Glyceryl Groups: Google Patents; 1965.

18. Bowen R. Composite and Sealant Resins: Past, Present and Future. Pediatr Dent. 1982;4:10-5.

19. Nicholson JW. The Chemistry of Medical and Dental Materials: Rsc (Rsc Materials Monographs). $2^{\text {nd }}$, CPI Group (UK) Ltd. Croydon UK, 2002.

20. Kanık Ö, Türkün LŞ. Restoratif Cam İyonomer Simanlarda Güncel Yaklaşımlar. Ege Üniv Dişhek Fak Derg 37:54-65.

21. Simonsen RJ. Pit and Fissure Sealant: Review of the Literature. Pediatr Dent . 2002;24:393-414.

22. Simonsen R, Neal R. A Review of the Clinical
Application and Performance of Pit and Fissure Sealants. Aust Dent J 2011;56:45-58.

23. Rock W, Potts A, Marchment M, Clayton-Smith A, Galuszka M. The Visibility of Clear and Opaque Fissure Sealants. Br Dent J 1989;167:395.

24. Dean JA, Avery DR, McDonald RE. Mcdonald and Avery's Dentistry for the Child and Adolescent/[Edited by] Jeffrey A. Dean, Dds, Msd, Chief of Staff, Office of the Chancellor, Indiana University-Purdue University Indianapolis, Ralph E. Mcdonald Professor of Pediatr Dent and Professor of Orthodontics, Indiana University School of Dentistry, Riley Hospital for Children at Iu Health, Indianapolis, Indiana, James E. Jones, Dmd, Msd, Edd, Phd, Professor and Chair, Department of Pediatr Dent, Indiana University School of Dentistry, Clinical Professor, Department of Pediatrics, Indiana University School of Medicine, Indianapolis, Indiana, Laquia A. Walker Vinson, Dds, Mph, Assistant Professor, Pediatr Dent , Indiana University, Indianapolis, Indiana2016.

25. Babu G, Mallikarjun S, Wilson B, Premkumar C. Pit and Fissure Sealants in Pediatr Dent. SRM Journal of Research in Dental Sciences. 2014;5:253.

26. Pinkham J. Çocuk Diş Hekimliği: Bebeklikten Ergenliğe: Atlas Kitapçılık; 2009.

27. Reddy VR, Chowdhary N, Mukunda K, Kiran N, Kavyarani B, et al. Retention of Resin-Based Filled and Unfilled Pit and Fissure Sealants: A Comparative Clinical Study. Contemporary clinical dentistry. 2015;6: S18.

28. Croll TP, Nicholson J. Glass Ionomer Cements in Pediatr Dent : Review of the Literature. Pediatr Dent . 2002;24:423-9.

29. Cho S, Cheng AC. A Review of Glass Ionomer Restorations in the Primary Dentition. JournalCanadian Dental Association. 1999;65:491-95.

30. Antonson SA, Antonson DE, Brener S, Crutchfield J, Larumbe J, et al. Twenty-Four Month Clinical Evaluation of Fissure Sealants on Partially Erupted Permanent First Molars: Glass Ionomer Versus Resin-Based Sealant. J Am Dent Assoc 2012; 143:115-22.

31. Naaman R, El-Housseiny A, Alamoudi N. The Use of Pit and Fissure Sealants-a Literature Review. Dent J 2017;5:34.

32. Nicholson JW, Czarnecka B. The Biocompatibility of Resin-Modified Glass-Ionomer Cements for Dentistry. Dent Material 2008;24:1702-8.

33. Papacchini F, Goracci C, Sadek FT, Monticelli F, Garcia-Godoy $F$, et al. Microtensile Bond Strength 
to Ground Enamel by Glass-Ionomers, ResinModified Glass-Ionomers, and Resin Composites Used as Pit and Fissure Sealants. J Dent 2005;33:459-67.

34. de Oliveira FS, da Silva SMB, Machado MAdAM, Bijella MFTB, Lima JEDO, et al. Resin-Modified Glass Ionomer Cement and a Resin-Based Material as Occlusal Sealants: A Longitudinal Clinical Performance. J Dent Child 2008;75.

35. Tyas M, Burrow M. Adhesive Restorative Materials: A Review. Aust Dent J 2004;49:112-21.

36. Pardi V, Carlos Pereira A, Luiz Mialhe F, de Castro Meneghim M, Maria Bovi Ambrosano G. Six-Year Clinical Evaluation of Polyacid-Modified Composite Resin Used as Fissure Sealant. Journal of Clinical Pediatr Dent . 2004;28:257-60.

37. Matalon S, Peretz B, Sidon R, Weiss EI, Slutzky H. Antibacterial Properties of Pit and Fissure Sealants Combined with Daily Fluoride Mouth Rinse. Pediatr Dent 2010;32:9-13.

38. Kaya DT, Tirali YDDRE. Cam Iyonomer Simanlardaki Gelişmeler. Atatürk Üniv Diş Hek Fak Derg 2013;23.

39. Bottenberg P, Alaerts $M$, Keulemans F. A Prospective Randomised Clinical Trial of One BisGma-Based and Two Ormocer-Based Composite Restorative Systems in Class Ii Cavities: ThreeYear Results. J Dent 2007;35:163-71.

40. Guler C, Yilmaz Y. A Two-Year Clinical Evaluation of Glass Ionomer and Ormocer Based Fissure Sealants. Journal of Clinical Pediatr Dent . 2013;37:263-8.

41. Durham S, Meyers E, Bailey C, Vandewalle K. Microleakage and Shear Bond Strength of a New Sealant Containing Prereacted Glass Ionomer Particles. General dentistry. 2017;65:e12-e16.

42. Ushimura S, Nakamura K, Matsuda Y, Minamikawa $\mathrm{H}$, Abe $\mathrm{S}$, et al. Assessment of the Inhibitory Effects of Fissure Sealants on the Demineralization of Primary Teeth Using an Automatic Ph-Cycling System. Dent Material J 2016;35:316-24.

43. Dionysopoulos D, Sfeikos T, Tolidis K. Fluoride Release and Recharging Ability of New Dental Sealants. European Archives of Paediatric Dentistry. 2016;17:45-51.

44. Zainuddin N, Karpukhina N, Law RV, Hill RG. Characterisation of a Remineralising Glass Carbomer $\AA$ Ionomer Cement by Mas-Nmr Spectroscopy. Dent Material 2012;28:1051-8.

45. Gorseta K, Glavina D, Borzabadi-Farahani A, Van Duinen R, Skrinjaric I, et al. One-Year Clinical
Evaluation of a Glass Carbomer Fissure Sealant, a Preliminary Study. Eur J Prosthod Res Dent 2014;22:67-71.

46. Subramaniam P, Girish Babu K, Jayasurya S. Evaluation of Solubility and Microleakage of Glass Carbomer Sealant. Journal of Clinical Pediatr Dent . 2015;39:429-34.

47. Chen X, Du M, Fan M, Mulder J, Huysmans M-C, et al. Effectiveness of Two New Types of Sealants: Retention after 2 Years. Clinical oral investigations. 2012;16:1443-50.

48. Kucukyilmaz E, Savas S. Of Glass Ionomer-Based Fissure Sealants. Eur J Paediatr Dent 2016;17:17.

49. Kühnisch J, Mansmann U, Heinrich-Weltzien R, Hickel R. Longevity of Materials for Pit and Fissure Sealing-Results from a Meta-Analysis. Dent Material 2012;28:298-303.

50. Simonsen RJ. From Prevention to Therapy: Minimal Intervention with Sealants and Resin Restorative Materials. J Dent 2011;39:S27-S33.

51. Casamassimo PS, Fields HW, McTigue DJ, Nowak A. Pediatr Dent : Infancy through Adolescence: Elsevier Health Sci; 2013.

52. Beauchamp J, Caufield PW, Crall JJ, Donly K, Feigal $R$, et al. Evidence-Based Clinical Recommendations for the Use of Pit-and-Fissure Sealants: A Report of the American Dental Association Council on Scientific Affairs. J Am Dent Assoc 2008;139:257-68.

53. Rathnam A, Nidhi M, Shigli AL, Indushekar K. Comparative Evaluation of Slot Versus Dovetail Design in Class Iii Composite Restorations in Primary Anterior Teeth. Contemporary clinical dentistry. 2010;1:6.

54. Duggal MS, Tahmassebi JF, Toumba KJ, Mavromati C. The Effect of Different Etching Times on the Retention of Fissure Sealants in Second Primary and First Permanent Molars. International journal of paediatric dentistry. 1997;7:81-86.

55. Maher MM, Elkashlan HI, El-Housseiny AA. Effectiveness of a Self-Etching Adhesive on Sealant Retention in Primary Teeth. Pediatr Dent . 2013;35:351-4.

56. Chadwick BL, Treasure ET, Playle RA. A Randomised Controlled Trial to Determine the Effectiveness of Glass Ionomer Sealants in PreSchool Children. Caries Res 2005;39:34-40.

57. Oong EM, Griffin SO, Kohn WG, Gooch BF, Caufield PW. The Effect of Dental Sealants on Bacteria Levels in Caries Lesions: A Review of the Evidence. J Am Dent Assoc 2008;139:271-8. 
58. Griffin SO, Oong E, Kohn W, Vidakovic B, Gooch B, et al. The Effectiveness of Sealants in Managing Caries Lesions. J Dent Res 2008;87:169-74.

59. Borges BCD, de Souza Borges J, Braz R, Montes $M A J R$, de Assunção Pinheiro IV. Arrest of Non-Cavitated Dentinal Occlusal Caries by Sealing Pits and Fissures: A 36-Month, Randomised Controlled Clinical Trial. International dental journal. 2012;62:251-5.

60. Zandona AF, Swift Jr EJ. Evidence for Sealing Versus Restoration of Early Caries Lesions. J Esthetic Res Dent 2015;27:55-8.

61. de Assunção IV, da Costa GdFA, Borges BCD. Systematic Review of Noninvasive Treatments to Arrest Dentin Non-Cavitated Caries Lesions. World Journal of Clinical Cases: WJCC. 2014;2:137.

62. Clinical ACRDS, Dentistry AAoP. Guideline on Pediatric Restorative Dentistry. Pediatr Dent. 2012; 34:173.

63. Hatibovic-Kofman S, Wright G, Braverman I. Microleakage of Sealants after Conventional, Bur, and Air-Abrasion Preparation of Pits and Fissures. Pediatr Dent 1998;20:173-6.

64. Pereira AC, Eggertsson $H$, Martinez-Mier EA, Mialhe FL, Eckert GJ, et al. Validity of Caries Detection on Occlusal Surfaces and Treatment Decisions Based on Results from Multiple Caries-Detection Methods. European Journal of Oral Sciences. 2009;117:51-7.

65. Meiers JC, Jensen ME. Management of the Questionable Carious Fissure: Invasive Vs Noninvasive Techniques. J Am Dent Assoc 1984;108:64-8.

66. Welbury R, Raadal M, Lygidakis N. Eapd Guidelines for the Use of Pit and Fissure Sealants. Eur J Paediatr Dent 2004;5:179-84.

67. Gray SK, Griffin SO, Malvitz DM, Gooch BF. A Comparison of the Effects of Toothbrushing and Handpiece Prophylaxis on Retention of Sealants. J Am Dent Assoc 2009;140:38-46.

68. Warren D, Infante N, Rice H, Turner S, Chan J. Effect of Topical Fluoride on Retention of Pit and Fissure Sealants. Journal of dental hygiene: JDH. 2001;75:21-24.

69. Yildiz E, Şimşek AGDM. İki Farklı Fissür Örtücünün Ve Polisaj Tekniğinin Klinik Değerlendirilmesi. Atatürk Üniversitesi Diş Hekimliği Fakültesi Dergisi.2013:337-41.

70. Zero DT. How the Introduction of the Acid-Etch Technique Revolutionized Dental Practice. J Am Dent Assoc 2013;144:990-4.
71. Feigal RJ, Hitt J, Splieth C. Retaining Sealant on Salivary Contaminated Enamel. J Am Dent Assoc 1993; 124:90.

72. Feigal R, Musherure P, Gillespie B, Levy-Polack M, Quelhas I, et al. Improved Sealant Retention with Bonding Agents: A Clinical Study of Two-Bottle and Single-Bottle Systems. J Dent Res 2000;79:1850-6.

73. Botton G, Morgental CS, Scherer MM, Lenzi TL, Montagner AF, et al. Are Self-Etch Adhesive Systems Effective in the Retention of Occlusal Sealants? A Systematic Review and Meta-Analysis. Int J Paediatr Dent 2016;26:402-11.

74. Nirwan M, Nigam AG, Marwah N, Nayak UA, Bansal A, et al. A Comparative Evaluation of Retention of Pit and Fissure Sealant Bonded Using Sixth-, Seventh-, and Eighth-Generation Adhesives: An in Vivo Study. JIndian Soc Pedodont Prevent Dent 2017; 35:359.

75. Feigal RJ. Sealants and Preventive Restorations: Review of Effectiveness and Clinical Changes for Improvement. Pediatr Dent 1998;20:85-92.

76. Romcke R, Lewis D, Maze B, Vickerson R. Retention and Maintenance of Fissure Sealants over 10 Years. J Canadian Dent Assoc 1990; 56: 235-7.

77. Griffin SO, Gray SK, Malvitz DM, Gooch BF. Caries Risk in Formerly Sealed Teeth. J Am Dent Assoc 2009;140:415-23.

78. Fleisch AF, Sheffield PE, Chinn C, Edelstein BL, Landrigan PJ. Bisphenol a and Related Compounds in Dent Material Pediatrics. 2010;126:760-68.

79. Kloukos D, Pandis N, Eliades T. In Vivo Bisphenol-a Release from Dental Pit and Fissure Sealants: A Systematic Review. J Dent 2013;41:659-67.

\author{
Yazışma Adresi \\ Uzm.Dt.Ece ÜNLÜGENÇ \\ Hatay Mustafa Kemal Üniversitesi \\ Tayfur Ata Sökmen Kampüsü \\ Diş Hekimliği Fakültesi \\ Serinyol/Antakya/Hatay \\ Tel: 0 (326) 2456060 \\ Fax: 0 (326) 2455060 \\ Email: eunlugenc@gmail.com
}

